\title{
TRENDS IN PREVALENCE OF ASTHMA IN CHILDREN BY THE EXAMPLE OF THE KYIV REGION OF UKRAINE
}

\author{
Duda L. V. \\ Shupyk National Medical Academy of Postgraduate Education, Kyiv, Ukraine \\ DOI: https://doi.org/10.31435/rsglobal_ws/30112019/6769
}

\begin{abstract}
ARTICLE INFO
Received: 18 September 2019

Accepted: 13 November 2019

Published: 30 November 2019

\section{KEYWORDS}

prevalence of asthma,

children,

wheezing,

Ukraine.

ABSTRACT

Asthma constitute a significant cause of morbidity worldwide and a considerable burden on the health and medical systems of both developed and emerging economies. The article presents the results of the study of the prevalence of asthma symptoms in children of different ages (from 0 to 18 years) in the Kyiv region of Ukraine. Quite high levels of "wheezing in the past 12 months" are noted: 6 mounth-5 years $24,6 \%$; 6-7 years $-18,7 \%$; $13-14$ years $-12,6 \%$; $15-17$ years $-9,2 \%$. But at the same time, the low level of asthma diagnosis remains an important problem in Ukraine. The levels of asthma symptoms, which may indicate a severe course of the disease, are also quite high. The article presents the results of similar studies in other countries for comparison.
\end{abstract}

Citation: Duda L. V. (2019) Trends in Prevalence of Asthma in Children by the Example of the Kyiv Region of Ukraine. World Science. 11(51), Vol.2. doi: 10.31435/rsglobal_ws/30112019/6769

Copyright: (C) 2019 Duda L. V. This is an open-access article distributed under the terms of the Creative Commons Attribution License (CC BY). The use, distribution or reproduction in other forums is permitted, provided the original author(s) or licensor are credited and that the original publication in this journal is cited, in accordance with accepted academic practice. No use, distribution or reproduction is permitted which does not comply with these terms.

Introduction. The prevalence of asthma has been steadily increasing among children and adults. Globally, asthma is ranked 16th among the leading causes of years lived with disability and 28th among the leading causes of burden of disease [1].

Today, despite the availability of effective therapy and prevention, the economic costs associated with asthma are only increasing worldwide. They are rated as one of the highest among chronic diseases. The greatest economic costs are for children and the elderly, as well as for women compared to men. Among the pediatric population, about $41.3 \%$ of the total amount is spent on medicines, which is significantly higher than in adults [2]. Also, the higher costs are spent for patients with comorbid pathology, which significantly complicates the course of asthma, and may also be one of the causes of resistance to anti-inflammatory therapy, which reduces the effectiveness of treatment and worsens the prognosis of the disease [3]. Severe asthma is often associated with comorbidities, including obesity, rhinitis, nasal polyps and food allergies [1]. The high rate of disability of children is usually due to the uncontrolled course of the disease due to poor diagnosis or lack of treatment of the disease or the low effectiveness of standard antiinflammatory therapy regimens (in $30 \%$ of children with asthma) [3].

All these important issues require resolution and settlement. This, in turn, led to the need for large-scale epidemiological studies with unified criteria, which allowed to collate data from around the world. An international epidemiological study was conducted to study the prevalence of allergic diseases in children. An international epidemiological - International Study of Asthma and Allergies in Childhood (ISAAC; http://isaac.auckland.ac.nz/) was conducted to study the prevalence of allergic diseases in children. ISAAC Phase One surveyed about 700,000 children from 156 centers in 56 countries and ISAAC Phase Three surveyed about 1,200,000 children from 233 centers in 98 countries (involving almost 800,000 children aged $13-14$ years and almost 400,000 aged 6-7 years) $[4,5]$. The study showed not only the true prevalence of asthma in the pediatric population, but also the dynamics of a minimum 5-year interval thanks to Phase Three and had studied the factors influencing the formation of asthma. 
The ISAAC affirms that the incidence of allergic diseases has grown into an epidemic. However, there is a large geographical variation in asthma prevalence, severity, and mortality. While asthma prevalence is higher in high income countries, most asthma-related mortality occurs in lowmiddle income countries [1,6]. The discrepancy between the incidence and mortality rates of asthma is observed in different countries. There is also an inverse correlation with socioeconomic status. The high prevalence of $\mathrm{AD}$ is observed in populations with low socio-economic development, as the population lives in poor conditions (by physical, social and psychological criteria). Due to a number of social, political and economic reasons, some populations become isolated in adverse environmental conditions, which may result in increased exposure to risk factors [4].

In particular, the ISAAC also showed the prevalence of severe asthma symptoms. Severe asthma is associated with the loss of lung function in childhood and is a major determinant of early chronic obstructive pulmonary disease (COPD). Therefore, prevention of severe childhood asthma should be a major component of efforts to reduce premature COPD mortality [1].

An epidemiologic study cannot solve all the problems of interest to the clinician, but it does help to establish a true picture of the prevalence of the disease, outline the range of issues, and identify specific categories of children who need more detailed study.

Methods and materials. The standardized questionnaires of the international program ISAAC were used to determine the prevalence of current symptoms of asthma [4]. During 2017-2019, survey was conducted at pre-schools and schools of the Kyiv region among children of the following age categories: 6 months-5 years (Group I - united pre-planned age categories 6 months-3 years and 4-5 years due to low the number of respondents), 6-7 years (Group II), 13-14 years (Group III), and 15-17 years (Group IV).

In accordance to the ISAAC program methodology, to obtain valid results, the sample size of 3000 children for each age group was recommended (in case of individual centers study, a minimum sample of 1000 people was allowed) [4, 7]. To establish a representative sample size, we used the formula for determining the sample size by Lisitsyn Yu. P. (1987) [8], according to which the optimal sample size was 7105 children.

The study was conducted in compliance with the current Ukrainian legislation and meets the international ethical requirements. The approval of bioethical expert commission is received. The permits issued by the Department of Education and Science and the Department of Health of the Kyiv region were obtained. Written questionnaires were completed by children's parents and by senior students on a voluntary basis. Educational institutions have been chosen randomly.

Data analysis was performed using " $R$ " version 3.6.0. software using nonparametric statistical processing methods to determine the significant difference between the two independent groups.

Research results. As a result of the study, 7106 correctly completed questionnaires were received at this stage, which is $98.6 \%$ of the respondents. The distribution by the age categories is following: Group I has 1787 children (, Group II - 2080 children, Group III - 1909 children, Group IV -1330 children. The gender distribution of the sample is about 1:1.

The prevalence of asthma symptoms among the surveyed pediatric population, namely the index "wheezing in the past 12 months», which corresponds to question \# 2 in each block of the questionnaire (were selected as the most sensitive criterion, based on the international experience of colleagues) has the rank of $16,8 \%(1192 / 7106)$, and among them is reliably higher in boys $-18,9 \%$ (645/3418), and in girls $-14,8 \%(547 / 3688)\left(\chi^{2}=20,439 ; p=0,000\right)$.

The distribution by age categories is following: Group I has $24.6 \%$ (440/1787), Group II $18.7 \%$ (388/2080), Group III - 12.6\% (241/1909), Group IV - 9, $2 \%$ (123/1330) - with a significant difference between the groups $(\mathrm{p}=0.000)$ (Table 1$)$. The highest rates of asthma symptoms prevalence are observed among children of the youngest age group, which, of course, is due to age-related anatomical and physiological features and features of the autonomic nervous system in young children. There is a gradual decrease in asthma incidence over the years, but they remain quite high. The same trends persist for "wheezing at any time in the past». Another indicator that may also indicate asthma in a child - "dry cough at night, apart from a cough associated with a cold or chest infection" - is quite high in Group I and II children, accounting for $17.2 \%$ and $18.0 \%$ respectively.

Table 2 and 3 presents the prevalence of wheezing by gender distribution. The prevalence of wheezing among boys is significantly higher than girls in Group I $\left(\chi^{2}=20,453 ; p=0,000\right)$. 
Table 1 The prevalence of symptoms of asthma in children in the Kyiv region (Ukraine), frequency, $\%$ symptoms of asthma Age groups

\begin{tabular}{|c|c|c|c|c|c|c|}
\hline \multirow{3}{*}{\multicolumn{2}{|c|}{ symptoms of asthma }} & \multicolumn{4}{|c|}{ Age groups } & \multirow[t]{3}{*}{$\mathbf{P}$} \\
\hline & & $\begin{array}{l}6 \text { months } \\
-5 \text { years }\end{array}$ & $\begin{array}{c}\text { 6-7 } \\
\text { years }\end{array}$ & $\begin{array}{l}13-14 \\
\text { years }\end{array}$ & $\begin{array}{l}15-17 \\
\text { years }\end{array}$ & \\
\hline & & $(\mathrm{n}=1787)$ & $(n=2080)$ & $(\mathrm{n}=1909)$ & $(n=1330)$ & \\
\hline \multicolumn{2}{|c|}{ 1.wheezing at any time in the past } & 31,6 & 28,3 & 26,2 & 20,3 & $<0,000$ \\
\hline \multicolumn{2}{|c|}{ 2.wheeze in the past 12 months } & 24,6 & 18,7 & 12,6 & 9,2 & $<0,000$ \\
\hline \multirow{4}{*}{$\begin{array}{l}\text { 3.attacks of wheezing in } \\
\text { the past } 12 \text { months }\end{array}$} & 1 & 7,7 & 6,5 & 4,2 & 5,0 & $<0,000$ \\
\hline & 2 to 3 & 11,1 & 8,0 & 5,4 & 5,0 & $<0,000$ \\
\hline & 4 to 12 & 5,0 & 3,5 & 1,8 & 1,2 & $<0,000$ \\
\hline & $>$ than 12 & 1,1 & 0,9 & 1,3 & 0,6 & 0,239 \\
\hline \multirow{3}{*}{$\begin{array}{l}\text { 4.How often, on average, } \\
\text { has your child's sleep } \\
\text { been disturbed due to } \\
\text { wheezing? }\end{array}$} & never & 11,3 & 10,8 & 8,6 & 6,4 & $<0,000$ \\
\hline & $\begin{array}{l}<\text { than } 1 \text { per } \\
\text { week }\end{array}$ & 7,9 & 5,6 & 3,6 & 2,6 & $<0,000$ \\
\hline & $\begin{array}{l}1 \text { or }>\text { per } \\
\text { week }\end{array}$ & 1,6 & 1,3 & 1,0 & 1,0 & 0,274 \\
\hline \multicolumn{2}{|c|}{$\begin{array}{l}\text { 5.Has wheezing ever been severe } \\
\text { enough to limit your child's speech to } \\
\text { only one or two words at a time } \\
\text { between breaths? }\end{array}$} & 4,0 & 1,8 & 2,2 & 1,9 & $<0,000$ \\
\hline \multicolumn{2}{|c|}{ 6.Has your child ever had asthma? } & 0,8 & 1,9 & 3,7 & 2,8 & $<0,000$ \\
\hline \multicolumn{2}{|c|}{$\begin{array}{l}\text { 7.Has your child's chest sounded } \\
\text { wheezy during or after exercise? }\end{array}$} & 5,1 & 5,2 & 7,9 & 8,0 & $<0,000$ \\
\hline \multicolumn{2}{|c|}{$\begin{array}{l}\text { 8.Has your child had a dry cough at } \\
\text { night, apart from a cough associated } \\
\text { with a cold or chest infection? } *\end{array}$} & 17,2 & 18,0 & 12,9 & 10,5 & $<0,000$ \\
\hline
\end{tabular}

Table 2 The prevalence of "wheezing in the past 12 months" among boys (symptom of asthma, as the most sensitive criterion)

\begin{tabular}{c|ccc} 
AGE (YEARS) & $\mathbf{N}$ & $\mathbf{\%}$ & $\mathbf{9 5 \%} \mathbf{C I}$ \\
\hline ALL & 645 & 18,9 & $17,6-20,2$ \\
$\mathbf{0 - 5}$ & 265 & 29,2 & $26,3-32,3$ \\
$\mathbf{6 - 7}$ & 210 & 19,6 & $17,3-22,1$ \\
$\mathbf{1 3 - 1 4}$ & 127 & 14,0 & $11,8-16,5$ \\
$\mathbf{1 5 - 1 7}$ & 43 & 8,1 & $5,9-10,7$
\end{tabular}

Table 3 The prevalence of "wheezing in the past 12 months" among girls (asthma symptom, as the most sensitive criterion)

\begin{tabular}{c|ccc|} 
AGE (YEARS) & N & \% & 95\% CI \\
\hline ALL & 547 & 14,8 & $13,7-16,0$ \\
$\mathbf{0 - 5}$ & 175 & 19,9 & $17,3-22,7$ \\
$\mathbf{6 - 7}$ & 178 & 17,6 & $15,3-20,1$ \\
$\mathbf{1 3 - 1 4}$ & 114 & 11,4 & $9,5-13,5$ \\
$\mathbf{1 5 - 1 7}$ & 80 & 10,1 & $8,0-12,4$ \\
\hline
\end{tabular}

Severe asthma symptoms (representative questions \#3 (had had> 4 attacks of wheezing in the past 12 months; > than 12 attacks of wheezing), \#4 (had had> 1 night per week sleep disturbance from wheeze), \#5 (have had wheeze affecting speech) are more clearly presented at Figure 1. Presented asthma symptoms, which may indicate the severity if this disease, are high enough. 


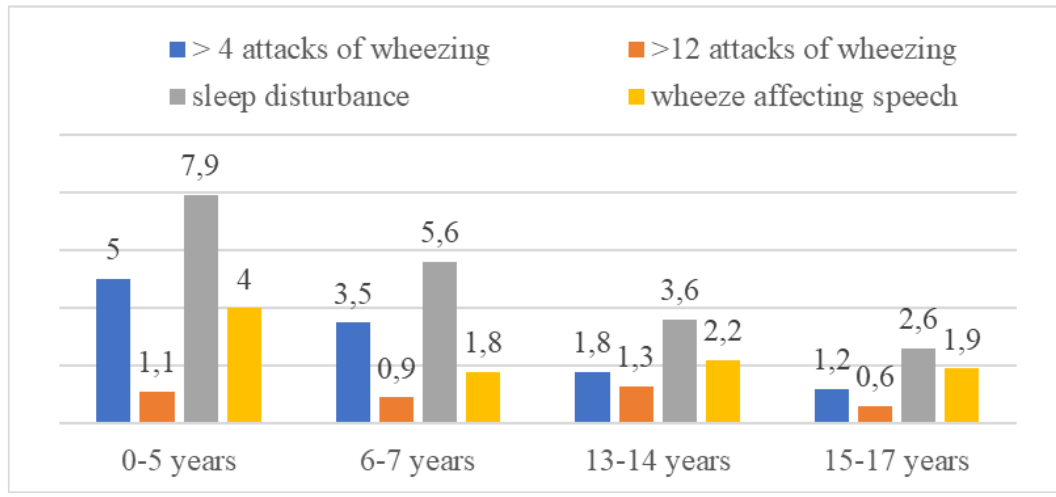

Fig. 1 The prevalence of severe asthma symptoms in children, \%

According to the obtained data, there are quite low levels of asthma confirmed by specialists in all age categories. Diagnosed asthma at the time of the survey: in Group I - 0.8\% (0.4-1.3), Group II - 1.9\% (1.3-2.6), Group III - 3.7\% (2, 9-4,6), Group IV - 2,8\% (2,0-3,8). While the prevalence of wheezing is much higher in all groups (Figure 2). Wheezing is not considered by doctors as an equivalent of the asthma attack, as a possible version of mild or moderate asthma.

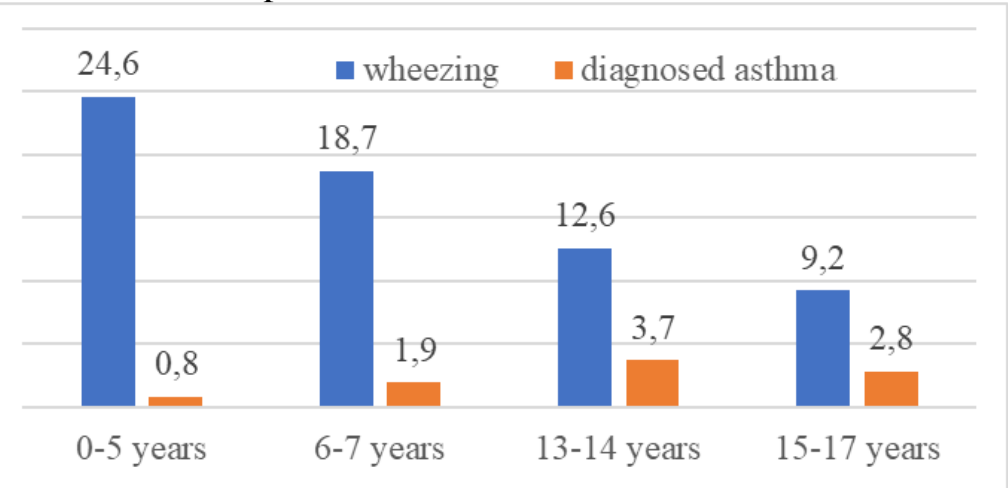

Fig. 2 Comparison of the prevalence of "wheezing over the past 12 months" with levels of diagnosed asthma, \%

ISAAC has demonstrated, by means of simple standardized questionnaires, that there are large variations in the prevalence of asthma symptoms throughout the world. The prevalence of asthma symptoms in different regions of Ukraine with neighboring countries, European countries and the world average can be compared using the data given in Table 3 and 4 [7, 8, 9]. We will continue to use for further analysis only the results from two age groups - Group II (6-7 years) and Group III (13-14 years) as provided by the methodology of the international ISAAC program [7].

High rates of wheezing in the past 12 months are observed, even compared to Kharkiv region (Ukraine) and neighboring countries, while at the same time low level of diagnostics compared to Europe, especially in the younger age category.

Table 3. Prevalence of current symptoms of asthma, by region among 6-7 years age children, $\%$

\begin{tabular}{|c|c|c|c|c|}
\hline Region & $\begin{array}{l}\text { wheeze in the past } \\
12 \text { months }\end{array}$ & $\begin{array}{l}\text { diagnosis of } \\
\text { asthma at any time }\end{array}$ & $\begin{array}{l}\text { wheeze during or } \\
\text { after exercise }\end{array}$ & $\begin{array}{l}\text { dry cough } \\
\text { at night }\end{array}$ \\
\hline Ukraine, Kyiv region & 18,7 & 1,9 & 5,2 & 18,0 \\
\hline $\begin{array}{l}\text { Ukraine, Kharkiv } \\
\text { region }\end{array}$ & 4,5 & 0,3 & 1,3 & 5,5 \\
\hline $\begin{array}{l}\text { Republic of Belarus } \\
\text { (Grodno region) }\end{array}$ & 9,3 & 2,9 & 1,7 & 8,2 \\
\hline Russia & $5,9-13,2$ & $0,66-9,6$ & $2,8-21,8$ & $7,8-13,6$ \\
\hline Western Europe & 8,1 & 7,2 & 3,7 & 16,1 \\
\hline $\begin{array}{l}\text { Northern and Eastern } \\
\text { Europe }\end{array}$ & 8,8 & 3,2 & 3,6 & 11,4 \\
\hline World average & $4,1-32,1$ & $1,4-27,2$ & $1,6-16,5$ & $5,9-39,5$ \\
\hline
\end{tabular}


Table 4 Prevalence of current symptoms of asthma, by region among 13-14 years age children, $\%$

\begin{tabular}{|l|l|l|l|l|}
\hline Region & $\begin{array}{l}\text { wheeze in the } \\
\text { past 12 months }\end{array}$ & $\begin{array}{l}\text { diagnosis of } \\
\text { asthma at any time }\end{array}$ & $\begin{array}{l}\text { wheeze during or } \\
\text { after exercise }\end{array}$ & $\begin{array}{l}\text { dry cough at } \\
\text { night }\end{array}$ \\
\hline Ukraine, Kyiv region & 12,6 & 3,7 & 7,9 & 12,9 \\
\hline Ukraine, Kharkiv region & 3,3 & 0,7 & 2,9 & 4,7 \\
\hline $\begin{array}{l}\text { Republic of Belarus } \\
\text { (Grodno region) }\end{array}$ & 9,1 & 4,1 & 12,8 & 14,6 \\
\hline Russia & $5,3-16,9$ & $0,66-8,9$ & $7,1-23,4$ & $6,2-17,8$ \\
\hline Western Europe & 16,7 & 13,0 & 20,0 & 27,1 \\
\hline $\begin{array}{l}\text { Northern and } \\
\text { Eastern Europe }\end{array}$ & 9,2 & 4,4 & 12,3 & 12,2 \\
\hline World average & $2,1-32,2$ & $1,6-28,2$ & $2,3-43,4$ & $4,0-42,3$ \\
\hline
\end{tabular}

Conclusions. The results of the study indicate a fairly high levels of asthma symptoms prevalence in Kyiv region of Ukraine, which is consistent with global trends. Wherein, low rates of diagnosed asthma in all age categories were detected. Asthma underdiagnosis remains super important problem in Ukraine. This lack of proper recognition often results in a lack of, or incorrect, diagnosis resulting in sub-optimal disease management, negative effects on quality of life, increased morbidity and mortality, and considerable additional direct and indirect costs [10]. The conducted study should inform doctors and public health care institutions first and urge scientists to further address the issues raised.

Conflict of interest. None declared.

\section{REFERENCES}

1. Shyamali C. Dharmage, Jennifer L. Perret, Adnan Custovic. (2019) Epidemiology of Asthma in Children and Adults. Front Pediatr. 2019; 7: 246. Published online 2019 Jun 18. doi: 10.3389/fped.2019.00246

2. Bahadori K, Doyle-Waters MM, Marra C, Lynd L, Alasaly K, Swiston J, FitzGerald JM. (2009) Economic burden of asthma: a systematic review. BMC Pulm Med. 2009;9:24. doi: 10.1186/1471-2466-9-24

3. Е Н Охотникова, Е В Шарикадзе (2015) Бронхиальная астма и аллергический ринит у детей до 6 лет: особенности терапии коморбидной патологии. Современная педиатрия, 7(71) pp. 111-116 doi:10.15574/SP.2015.71.111

4. Duda L. V., Okhotnikova O. M. (2018) Clinical and epidemiological characteristics of the most common allergy diseases in children. Child's Health, т. 13, no 4. pp. 345-355 doi: 10.22141/22240551.13.4.2018.137017

5. J. Mallol, J. Crane b, E. von Mutius c, J. Odhiambo d, U. Keil e, A. Stewartf, the ISAAC Phase Three Study Group. (2013) The International Study of Asthma and Allergies in Childhood (ISAAC) Phase Three: A global synthesis. Allergologia et Immunopathologia_Volume 41, Issue 2, March-April 2013, Pages 73-85 https://doi.org/10.1016/j.aller.2012.03.001

6. David A. Hill, Robert W. Grundmeier, Gita Ram, Jonathan M. Spergel. (2016) The epidemiologic characteristics of healthcare provider-diagnosed eczema, asthma, allergic rhinitis, and food allergy in children: a retrospective cohort study. BMC Pediatrics December 2016 doi: 10.1186/s12887-016-0673-z

7. Duda, L., Okhotnikova, O., Sharikadze, O., \& Zubchenko, S. (2019). COMPARATIVE ANALYSIS OF PREVALENCE OF THE MOST COMMON ALERGY DISEASES IN CHILDREN OF THE KYIV REGION (UKRAINE). Georgian medical news, (291), 53-58.

8. Asher M.I., Keil U., Anderson H.R., et al. (1995). International Study of Asthma and Allergies in Childhood (ISAAC) - Rationale and Methods. European Respiratory Journal. 8(3);483: 91.

9. Khokha R.N., Paramonova N.S. Bronchial asthma symptoms and diagnosis prevalence in children at the Grodno region as a representative of the Republic of Belarus according to the ISAAC program (phase I). Russian Pulmonology. 2015;25(1):77-81. (In Russ.) https://doi.org/10.18093/0869-0189-2015-25-1-77-81

10. Björn Nordlund, Erik Melén, Erica S. Schultz, Hans Grönlund, Gunilla Hedlin (2014) Prevalence of severe childhood asthma according to the WHO. Respiratory Medicine_Volume 108, Issue 8, August 2014, Pages 1234-1237 https://doi.org/10.1016/j.rmed.2014.05.015 